\title{
Turismo Religioso no Brasil: uma perspectiva local e global
}

Religious Tourism in Brazil: a local and global perspective

Emerson J. Sena da Silveira

\begin{abstract}
RESUMO: $\mathrm{O}$ artigo discute a pertinência conceitual do termo turismo religioso no contexto da pós-modernidade. Há em andamento uma capacidade de geração de negócios, de fomento social e econômico, de atrativos de cunho religioso em países de tradição ibérica e em desenvolvimento, particularmente no Brasil, foco do presente artigo. Se, por um lado, o conceito revela certa ambigüidade, por outro, as oportunidades de negócio revelam um "campo etnográfico" para investigação antropológica.
\end{abstract}

PALAVRAS-CHAVE: turismo religioso; oportunidades de negócio; festas religiosas; perspectiva global e local.

ABSTRAC: The present article discusses, simultaneously, the conceptual pertinence of the term religious tourism and the empiric capacity of this activity in generating business and, therefore, in producing social and economic development. If by one side, the concept reveals itself fragile, by another the

1. Antropólogo, doutor em Ciência da Religião, pela Universidade Federal de Juiz de Fora - UFjF, e professor (Faculdade Machado Sobrinho, Faculdade do Sudeste Mineiro - Juiz de Fora. MG). Publicou os livros Por uma sociologia do turismo (Porto Alegre: Zouck, 2007), e Apresentação de trabalhos acadêmicos, em co-autoria com José Maria (Petrópolis: Vozes, 2007). Co-organizou e é co-autor (com Reinaldo Dias) do livro Turismo religioso: ensaios e reflexões (Campinas: Alínea, 2003). Pesquisa, na área de Ciências Sociais, o turismo "religioso", as religiosidades católico-carismáticas e as terapêuticas "religiosas”. Contato: Rua Diogo Álvares, 314 - 36090-320 - Juiz de Fora-MG; e-mail: emerson.jsena@ terra.com.br. 
business opportunities still remain few explored by business men, tourism professionals and governments.

KEYWORDS: religious tourism; business opportunities; religious fests; global and local perspective.

\section{Introdução}

Pretende-se colocar aqui algumas reflexões acerca do conceito e da prática social que vêm sendo denominados como "turismo religioso" (Amirou, 1995; Steil, 1998).

As atuais transformaçōes que ocorrem no campo religioso no Brasil e no mundo, quando das relaçōes estabelecidas com esferas não-religiosas, como turismo, lazer e política, parecem criar uma ambigüidade conceitual-teórica interna relativa ao termo turismo religioso.

Amirou (1995) e Graburn (1995) abordaram a possibilidade de intersecção entre duas dimensões que consideram fundamentais na experiência humana: a religião, na forma de peregrinação, e a viagem, enquanto deslocamento temporário, na forma do turismo.

Para Amirou (1995), tanto a peregrinação quanto o turismo seriam, mais do que uma experiência histórica, uma forma de deslocamento espacial, categorias de compreensão, que expressam duas formas de sociabilidade humana: a peregrinação, remetendo ao modelo de Victor Turner de communitas; e o turismo, ao modelo de sociedade de corte, no sentido proposto por Norbert Elias.

Entretanto, na proposição de Graburn (1995), o turismo seria um sucedâneo da experiência religiosa antiga e medieval, expressa na peregrinação enquanto busca pelo sagrado, que sai de uma estrutura do cotidiano e forma, provisoriamente, uma communita.

Contudo, nessas abordagens, os conceitos permanecem separados, dirigem-se a duas realidades diferentes, mas que, na prática, quando se analisam as visitas a santuários, poderiam estar imbricados ou, para se usar um termo "pós-moderno", seriam sincréticas, híbridas (Canclini, 2000).

Assim, ao serem articulados elementos das mais variadas fontes, como jornais, pesquisas, monografias, livros e artigos, festas religiosas, jubileus e outras manifestações populares, além da própria pesquisa de campo sobre o tema, o artigo indaga sobre a possibilidade de se constituir uma categoria que mapeie os deslocamentos estruturais que fazem da cultura popular um espaço de hibridação (Canclini, 2000).
Simultaneamente, a partir de estatísticas de viagens e motivações, entre outros aspectos do turismo consultados em órgãos como a Fundação Instituto de Pesquisas Econômicas - FIPE da Universidade de São Paulo (FIPE, 2002), o artigo apresenta tal segmento como uma oportunidade de negócios e área de trabalho ainda pouco valorizada pelo turismo. Um levantamento feito pela FIPE mostra que há cerca de 15 milhōes de brasileiros interessados em destinos religiosos (Melo, 2000). No mundo, esse número sobe para 60 milhōes, se forem consideradas apenas as religiōes cristãs (Melo, 2000). A maioria dos temas religiosos desses destinos é popular: procissões, festas, católicas ou não.

Afinal, é correto afirmar que todos os que vão a um templo, os que visitam um santuário estão fazendo "turismo religioso"? E o que o romeiro/peregrino faz, ao esfolar seus joelhos, ao pagar promessas, ao orar contrito no templo? Turismo religioso, ou romaria, peregrinação, fé? Esses elementos estão relacionados ao sério, ao íntimo, ao interior, enquanto turismo está ligado a posturas de ser, de viver, a uma experiência mais lúdica de divertimento, leveza, ao exterior, ao ver. O turismo remete à produção do espetáculo, no qual turistas se exteriorizam em uma relação, não a de conhecer o outro, mas a de estabelecer uma melhor definição de si, o que ocorre também com o passado dele. Mas a religião pode também ser compreendida como espetáculo, divertimento, visão e exterioridade (cores, símbolos).

Segundo Ardoino (1983), a polissemia da implicação acaba por construir termos, no caso turismo religioso, que expressam uma determinada prática social em que as fronteiras entre o consumo, o sagrado, a arte e o lúdico se tornam porosas, borradas. Há uma síntese produzida pela circulação de corpos, emoçōes e sentimentos (Reddy, 1990), mediados pelo consumo e pelo mercado (Appadural, 1996).

\section{A nomenclatura dos fenômenos turísticos e sócio-religiosos}

Surgido por volta da década de 1960 (Monteiro, 2003), o termo turismo religioso tem alcançado uma enorme utilização por parte dos setores ligados à reflexão acadêmica sobre o turismo, dos empresários do setor, da própria Igreja Católica. Mas é usado de forma acrítica (Silveira, 2003), confundindo-se com outros, como romaria, peregrinação etc.

Isso constitui um anacronismo, um artifício de retórica. No entanto, na contemporaneidade, é possível aplicar-se a categoria de "turismo religioso" ao deslocamento de visitantes em direção a lugares sagrados, templos ou festas?

Para Steil (1998), o significado é bem preciso: pode-se falar em turismo religioso quando o sagrado migra como estrutura de percepção para o cotidiano, 
para as atividades festivas, para o consumo, para o lazer. Assim, os turistas passam a participar de eventos como o Natal, não mais os vinculando à tradição cristã, mas relacionando-os a uma experiência inusitada, espiritual e consumista ao mesmo tempo, na qual a questão da autenticidade é recolocada. A experiência turística se transforma, então, em um estilo, produzindo um determinado nível de reflexividade (Giddens, 1990).

O turismo religioso, antiga prática social renomeada agora, em tempos de globalização e desterritorialização, constitui-se em visitar lugares considerados sagrados, usando-se estrutura de hospedagem. Acaba sendo adjetivado de turismo esotérico ou místico (São Thomé das Letras, Matutu, ambas cidades de Minas Gerais), evangélico etc.

Em Gramado e Canela (Rio Grande do Sul), que atraem turistas pelos seus festivais de chocolate e cinema, o Natal Luz não faz referência quase nenhuma ao nascimento de Cristo (Steil, 1998); nessas cidades, o Papai Noel desce de rampas e faz malabarismos, fica ao lado de duendes e bruxas. Torna-se sagrado o consumo e a experiência de participar dessa exteriorização, o que se contrapõe aos autores que vêem no turismo religioso uma perda da autenticidade, apenas uma encenação teatral (Boorstin, 1992). Na síntese que se forma a partir do turismo religioso, elementos como a cultura popular, a urbana e a religiosa juntam-se, tornando-se um amálgama, um híbrido.

Contudo, o que seria propriamente turismo religioso? Em que ele se diferencia das peregrinações, romarias, promessas e viagens religiosas de visitação a lugares sagrados? Os mesmos sentimentos não animam turistas e romeiros, por exemplo.

É fato que locais de culto e manifestações religiosas, eventos de cunho místico-espiritual atraem turistas, romeiros e fiéis, que vão aos mesmos lugares e festas. Dessa forma, nem toda viagem é turismo e vice-versa. Entretanto, na teoria de Maffesoli (2001: 23), o turismo poderia ser uma insurgência:

O fechamento praticado durante toda modernidade mostra, por todos os lados, sinais de fraqueza. Pouco importa [...] os que representam seus vetores: hippies, vagabundos, poetas, jovens sem ponto de referência ou mesmo turistas surpreendidos nos circuitos de férias programadas.

Para muitos o turismo é uma circulação, um deslocamento peculiar surgido no século XIX, embora suas raízes possam ser identificadas no século XVIII (Boyer, 1996). Não pode ser reduzido, o fenômeno turismo, a outros aspectos sociais, como a viagem (Omena, 1989), mas sim analisado em suas interfaces e seus entrecruzamentos com tantos aspectos da vida social, como a religiosidade.
Pode-se pensar, com razão, que há um certo grau de arbitrariedade entre o signo (sinal, símbolo) e o significante (aquilo a que se refere o sinal, símbolo) (Sapir, 1994). Por isso, ao se pronunciar a expressão "turismo religioso", colocamse em contato duas dimensões aparentemente opostas (Silveira, 2003): a atitude de lazer, descompromissada; e a atitude de fé, relacionada à identidade, a ritos, a valores. Contudo, na atual configuração do campo religioso no Brasil, não se pode tomar a religião como dotada de uma substância imutável, refratária a atitudes de lazer, divertimento.

Deve-se perguntar também quem pronuncia, como o assinalado por Foucault (2001), o discurso; o poder de nomear e de tomar para si e para os outros a "verdade" também é poder de influenciar, é poder político, pois não existe discurso neutro. Estão aí a exemplificar novos arranjos, como a aeróbica de Jesus ${ }^{2}$, os "showmissas" do Padre Marcelo ${ }^{3}$, a presença e a atuação midiáticas do Papa João Paulo II, o Carnaval com Cristo da Renovação Carismática Católica e de outras denominações cristãs (Dias; Silveira, 2003). Tudo isso tem sido interpretado no conjunto de transformações socioculturais, denominado como "pós-modernismo" por alguns pesquisadores (Harvey, 1989), e pós-modernidade, por outros (Carvalho, 1992). Carvalho (1999) referiu-se à sociedade brasileira como um grande campo plurivocal, multidiverso em termos religiosos, que abarca as mais diversas manifestações: Catolicismo; Protestantismo; tradições afro-brasileiras, como Candomblé, Umbanda e Xangô; Nova Era; Teologia da Libertação; práticas xamânicas, entre outras.

O pluralismo religioso se intensificou na sociedade brasileira a partir de 1980 e 1990, décadas em que a modernização industrial e a urbanização se aceleraram em torno das capitais e das cidades de médio porte. Professado por $91 \%$ da população em 1970, o Catolicismo caiu para 73\% em 2004, e, em algumas cidades, como o Rio de Janeiro, chegou a 57\%. O Protestantismo, no geral, é professado por $17 \%$ da população brasileira. Também são décadas de construção de um "mercado turístico nacional". Em 1996, o Instituto Brasileiro de Turismo (EMBRATUR)

2. Que, no Brasil, se expressa pela união entre um tipo de ginástica aeróbica e música religiosa. 3. Padre Marcelo Rossi, nascido em São Paulo, Brasil, notabilizou-se pelo uso dos meios de comunicação (rádio, TV e Internet), pelas músicas dançantes e alegres, pelo uso de uma gesticulação intensa nas missas, em oraçōes de cura etc.

4. A embratur foi fundada pela ditadura militar (1964-1985), em 1966, para fomentar as atividades econômicas e sociais que envolvem o turismo. Em 1991, seu nome foi mudado para Instituto Brasileiro de Turismo, com novas políticas públicas. Nos anos 2001/2002, foi implantado o Plano de Municipalização do Turismo. Em 2004, mudaram-se as diretrizes, e foi elaborado o Plano de Regionalização do Turismo. 
investiu pesado em programas de incentivo ao turismo, ao emprestar dinheiro para a construção de extensas redes de hotelaria.

É nesse contexto que a "pós-modernidade" vai referir-se à construção de experiências que implodem as fronteiras cartesianamente estabelecidas entre religião, turismo e cultura popular, instalando um fluxo de identificações em que emerge, na absorção da categoria mercadológica, parte dos agentes religiosos, sobretudo a partir dos meios de comunicação. Talvez seja isso o que a categoria "turismo religioso" expresse: a plurivocalidade na concretude do fazer político hegemônico da religião em sociedades periféricas como a brasileira. É nesse contexto que essa categoria emerge; inicia-se, assim, uma espécie de "transversalização", ou seja, perpassa-se, viaja-se desde as esferas dos agentes econômicos do turismo (agências de viagem, especialistas em turismo etc.) à nomenclatura de determinados agentes eclesiásticos (Assunção, 2002).

Por conseguinte, ao se naturalizar o termo "turismo religioso", operou-se um deslocamento etimológico no significado das palavras/termos, o que permite inferir as transformações operadas no eixo religião/política/turismo/cultura.

No Brasil, o local de origem dessa categoria é o mercado; os fluxos de visitantes a igrejas, a monumentos e a eventos religiosos são mediados por agentes turísticos, com o consumo daí resultante. Disso iniciou-se a captura e a geração de novas estruturas, a ponto de, no Brasil, a Igreja criar a Pastoral do Turismo, existente na Europa desde a década de 1960 (Pontificio Consejo..., 2003). Segundo a Conferência Mundial de Roma, de 1960, o turismo religioso movimenta peregrinos em viagens pelos mistérios da fé ou da devoção a algum santo. Na prática, são viagens organizadas para locais sagrados, eventos ligados à evangelização, festas religiosas periódicas, espetáculos de cunho religioso.

Contudo, a mudança de significado verificada nos termos religião e turismo, bem como sua inter-relação, dão margens à expressão "turismo religioso", o que aponta as atuais relações entre os campos supracitados, onde se localizam oportunidades de negócio, para empresários e comunidades locais. A expressão "turismo religioso" adquiriu foros de conceito (Dias; Silveira, 2003 e Silveira, 2003). Para alguns, a expressão é assumida e naturalizada (Carvalho, 2002; Abumansur, 2003). Há pesquisador que a assume sem problematizar, outros a questionam; e assim também o é para membros da Igreja e do Governo. Em uma pequena nota oficial (Basseti, 2001) de Ponta Grossa, Paraná, pode-se ler:

Acontece [...] na Igreja Batista Independente, [...] um encontro entre o Secretário Municipal de Turismo e Meio-Ambiente, Jorge Rosas Demiate, e os integrantes da Associação dos Ministros Evangélicos de Ponta Grossa. Na ocasião, o secretário irá expor os objetivos do projeto de turismo religioso, uma excelente alternativa para o desenvolvimento da cidade. Segundo o vice-presidente do Instituto Brasileiro de Marketing Cristão e consultor da Rede Vida de Televisão, Antônio M. Kater Filho, "o turismo religioso é uma das mais antigas atividades da história, bem como um gerador mundial de riquezas [...]". Para reforçar a afirmação, o consultor da Rede Vida mostrou números referentes a esse segmento: 4,5 trilhões de dólares em todo mundo, 192 milhões de empregos [...].

Sob o termo "turismo religioso", agentes religiosos, empresariais, públicos $e$ acadêmicos constituem uma ação articulada no sentido de extrair de práticas seculares de fé, como as peregrinações, caminhos santos e promessas, uma oportunidade de negócio, e, nos discursos mais otimistas, desenvolvimento socioeconômico de uma determinada região.

$\mathrm{Na}$ Itália, sujeitos religiosos ligados à Igreja já criaram uma organização da Secretaria Nacional para a Pastoral do Tempo Livre, do Turismo e do Esporte (Cristofoli, 2003), algo que algumas vozes eclesiásticas ensaiam no Brasil (Cristofoli, 2003). Segundo os documentos eclesiásticos (Pontificio Consejo..., 2003), ao se explicar o turismo, coloca-se o acento na:

Innata disposición del hombre a desplazarse se ha visto impulsada por el acelerado desarrollo de los medios de comunicación, así como por una mayor libertad de movimiento entre los países y de una mayor homogeneización legal y social. En el pasado fueron las condiciones naturales o sociales adversas las que impulsaron y obligaron a grupos más o menos numerosos de personas a cambiar su lugar de asentamiento. Nunca faltaron, sin embargo, viajeros que se pusieron en camino con el deseo de conocer otros pueblos, establecer relaciones con otras culturas o adquirir una visión más global de la realidad.

No entanto, o deslocamento etimológico das palavras, por meio do qual os significados se tornam porosos e ancorados em uma suposta "origem" (impulso inato, desejos primordiais), é realizado pela criação de mitos de origem, mantidos pela retórica discursiva, levada à exaustão pelos agentes, atores e comunidades situados no turismo, na instituição eclesiástica e na política.

Na cidade de Nova Trento, em Santa Catarina, um padre é responsável pelo monitoramento de excursões a lugares sagrados, que atraem mensalmente cerca de 30 mil pessoas, além de ser membro do Conselho Estadual de Turismo e coordenador da Pastoral do Turismo Religioso da Diocese de Florianópolis (SC) (Assunção, 2002). Agentes políticos também difundem a expressão “turismo religioso". Em um trecho de 2003 do site oficial do Governo da Paraíba lê-se que:

O governo do Estado quer primeiro consolidar a vinda de turistas para a capital [...] O ecoturismo e o turismo religioso estão dentro deste projeto, 
que começará pela capital e se desenvolverá por cidades do Brejo e do Sertão. Os caminhos do Padre Ibiapina já vêm sendo discutidos com a Igreja: deve começar por Guarabira, onde existe uma grande estátua de Frei Damião, até chegar ao Santuário de Padre Ibiapina, em Santa Fé de Arara.

Essa imbricação de agentes e esferas pode tingir-se de conflitos, como está estampado na reportagem do Jornal do Brasil (09/06/2002):

O governo do Estado de Santa Catarina, Brasil, quer que os restos mortais de Madre Paulina, canonizada em maio pelo Vaticano, sejam levados para o Estado como forma de incrementar o turismo religioso na região [...] Os restos mortais da santa estão na sede mundial da Congregação das Irmãzinhas da Imaculada Conceição, em São Paulo [...].

Existe até mesmo uma disciplina chamada "Turismo Religioso Nacional e Internacional", oferecida pelo Serviço de Aprendizagem do Comércio - SENAC no curso de Turismo e Hotelaria (SENAC, 2003). Em sua ementa, diz-se que é preciso:

Conhecer os destinos históricos do turismo religioso no Brasil e no Mundo, as implicações culturais e econômicas da atividade, o potencial turístico de cada um dos destinos para elaborar roteiros ligados à fé cristã e à espiritualidade. Deverá ainda ter condições de avaliar e caracterizar o produto final, o mercado e as formas de comercialização.

Contudo, entre figuras esquecidas e outras com potenciais atrativos religiosos em pequenas cidades de interior, algumas são personagens que nem foram canonizados, mas lhes são atribuídos qualidades e poderes divinos, de modo que os lugares onde viveram, onde realizaram milagres e curas divinas, e onde estão enterrados atraem fluxos de visitação, o que canaliza recursos econômicos para essas localidades. No entanto, se há a necessidade de aumentar uma nova tessitura de conceitualizações, aumentou-se a ambigüidade e a imprecisão epistemológica de tantas categorias, acadêmicas e descritivo-estatíticas, como as que têm sido largamente utilizadas no mercado turístico - entre elas, o próprio termo "turismo religioso".

\section{Turismo religioso: raízes "pós-modernas”?}

Até aqui se discutiu a imbricação entre turismo e religião. Todavia, até que ponto as manifestações populares de fé, como a Festa do Divino, que ocorre em alguns
Estados, podem ser consideradas turismo religioso? Daí o sentido contraditório no subtítulo: raízes "pós-modernas", colocado entre aspas para amenizar-se a aporia da expressão. Mas raízes de um formato diferente: não uma raiz de desenho axial, mas um rizoma, algo que Deleuze (apud Barreto, 2001) utilizou em sua argumentação sobre as transformações contemporâneas da identidade e da sociedade.

O rizoma não tem início nem fim definidos, nem eixo principal, nem fronteira nítida. Ele se espalha como uma rede pelo solo. Talvez a expressão turismo religioso, ainda que questionável, refira-se a um "rizoma" que entrelaça, em forma randômica, a expressão popular da cultura, o deslocamento turístico e a religião. Esse processo só pode ser entendido a partir da expansão do consumo como forma de sociabilidade da cultura "pós-moderna”. Consumo, logo existo, numa paródia à frase de Descartes. Contudo, a partir da expansão desse mercado, e porque a religião perde as coordenadas que a fixavam em determinado arranjo social, surgiu o que alguns autores denominaram como turismo religioso (Steil, 1998).

Centros da religiosidade popular como Aparecida (Brasil), Lourdes (França), Fátima (Portugal), que atraem a circulação de milhares de pessoas, passagem de fluxos e comunicação, desejos, comércio, ritos, tornam-se mais do que elementos de fé, de crença, de peregrinação e de romaria; transformam-se num espaço no qual se desenrolam práticas de deslocamento e consumo que, acopladas à forma como a religião se apresenta, fabricam um novo tipo de arranjo social. Hervieu-Léger (1997) identificou um profundo processo de dessimbolização, ou perda da eficácia do símbolo na esfera religiosa que, paradoxalmente, trouxe à sociedade laica a emoção, a experiência religiosa como o cerne de religiosidades emergentes, reconfigurando-se outros tipos de experiência: a viagem, o prazer, o fluxo turístico.

Paralelamente, o turismo tornou-se uma prática de consumo intensamente divulgada e, segundo Bauman (1998), um sintoma exemplar dos novos arranjos sociais da "pós-modernidade". Há uma relação entre a religião (forma) e o consumo/viagem/deslocamento (conteúdo), na qual a tradição peregrínica é compassada pelo turismo, forma secular de sociabilidade, rearranjos demonstrados com clareza conceitual nos estudos de Steil (1998; 2003).

Porém, um novo dado surge nesse cenário. Entre política, religião e turismo, constitui-se uma relação insuspeita, simultânea e sincrética de instrumentalização, de identificação, de afinidade semântica, passível de visualização através de alguns fatos. Aí existe oficialização de feriados e festividades religiosas, como "festas e eventos" de interesse turístico em Estados brasileiros. Para alguns eventos, como o Círio de Nazaré, no Pará, foram construídos espaços destinados ao turista, para que este contemple o "espetáculo exótico" de uma multidão que se autoflagela ao pagar promessas, ao buscar bênçãos divinas. Inúmeros outros dados apontam para uma certa instrumentalização política da religião na produção de atratividade turística. 
Todavia, interessa a este artigo investigar não tanto essa relação como parte de uma estratégia deliberada, mas sim como uma nova região na qual o sagrado vaise mesclar, lembrando o conceito de hibridização de Canclini (2000) com outras regiões da realidade. Por isso, a pergunta: até que ponto o turismo religioso pode ser compreendido como um arranjo de sociabilidade e um campo de negócios? Conceitualmente, o termo é impreciso; entretanto, pode servir para pensar um entrelaçamento de fenômenos em ação.

Historicamente, segundo Boyer (1996), a massificação do turismo ocorreu entre o século XVIII e o início do XX, fruto de novos problemas e novos discursos. O terapêutico-higienista, no século XIX (Boyer, 1996), por exemplo, levou à difusão da prática turística pelas camadas de amplos segmentos sociais na Europa. Havia um controle e uma disputa política de tal forma que:

A fé na virtude das águas e no valor terapêutico da temporada estival das estações termais foi consagrada nos escritos dos médicos-autores de guias. Eles tentavam retomar em suas mãos práticas populares; a Academia de medicina engajou-se na luta e levou o Estado a criar leis e regulamentos [...] para que as águas fossem sempre administradas sob o controle de médicos inspetores, nomeados pelo Estado.

Nesse sentido, o deslocamento turístico acabou incorporando o discurso higienista. Assim, destacam-se, a seguir, brevemente alguns nódulos desse rizoma.

\section{Festas religiosas populares}

Ligadas ou não à tradição católica, elas são comuns na maior parte dos municípios brasileiros. Segundo Perez (2000), são as atividades urbanas mais antigas do Brasil, junto às procissões. Podem ser citadas: festas de padroeiros; festas em honra a Maria, sob os diversos títulos (Imaculada Conceição, Nossa Senhora Aparecida etc.), entre outras. Com séculos de história, elas se espalham por extensa faixa territorial, passando por cidades dos Estados de Goiás, São Paulo e Rio de Janeiro. Algumas são realizadas há cerca de cem, duzentos anos (Pereira, 2003); reúnem-se, aproximadamente, 10 mil pessoas nos dias de festa. Barracas coloridas disputam espaço com as prédicas eclesiásticas. Fiéis e visitantes se acotovelam no comércio movimentado. A mídia e a política transformam, parcialmente, o ritual em espetáculo religioso com fins comerciais. Trajetos são alterados em função dos turistas. Fotos e reportagens fazem do evento um "turismo religioso". Mas qual o significado das festas para quem as vivencia? Há aí um paradoxo entre o olhar que mira do exterior, o turista; e o olhar que mira do interior das tradições, o peregrino, o fiel.
A EMBRATUR já publicou um roteiro de turismo religioso, que parece bem restrito ao Catolicismo. Cerca de $90 \%$ de seu conteúdo descrevem festas centenárias, surgidas antes do turismo. Mas quase nada se fala das religiosidades afrobrasileiras, orientais, protestantes e pentecostais etc. Enfim, não se contempla a diversidade religiosa brasileira. Se ela existe, existe também a possibilidade de se aproveitá-la dentro de um planejamento turístico.

\section{Lugares e eventos aos quais acorrem fluxos de turistas}

O Vale do Amanhecer, lugar criado pela vidente Tia Neiva, em Brasília, no Distrito Federal, é uma inédita hibridização de elementos esotéricos, cristãos e outros, articulados em uma arquitetura peculiar e ritos/vestuário, canto, singulares pela cor, forma, arranjo (Carvalho, 1999); o Templo do Ecumenismo Irrestrito (Brasília), pertencente à Legião da Boa Vontade (movimento religioso brasileiro de cunho esotérico), recebe, anualmente, cerca de 40 mil pessoas; as festas de Iemanjá, na Bahia, recebem 100 mil visitantes; além de outros locais, com famosas igrejas barrocas. Há exemplos, como a cidade de Aparecida (São Paulo) e a cidade de Belém (Pará), com a festa do Círio de Nazaré, que chegam a receber, respectivamente, seis e 3 milhões de pessoas, entre peregrinos e turistas.

\section{Caminhos "sagrados"}

Consistem em determinados trechos espaciais que um certo número de devotos e de turistas percorre entre locais considerados sagrados, como uma igreja, uma ermida, capelas etc. Um dos mais famosos é o de Santiago de Compostela, na Espanha. No Brasil, os caminhos foram criados ou já existiam, e foram canalizados por empresários, governos locais e pela Igreja (Gazoni, 2003), entre eles: Caminho do Sol, Caminho da Luz, Passos de Anchieta etc. O potencial de popularização desses caminhos é enorme.

\section{Turismo religioso na Internet}

Alguns agentes religiosos estão assumindo essa relação mercadológica. Em 2003, foi criado pela Arquidiocese de Belo Horizonte, Minas Gerais, um site que disponibiliza um link denominado "turismo religioso", que sugere: 
Belezas naturais, obras de arte e aspectos da história do nosso País. Estas são características de dezenas de igrejas da nossa Arquidiocese. Passeie "virtualmente" por algumas imagens que selecionamos e procure perceber a expressão de louvor ao Deus todo-poderoso, através das pinturas, esculturas, vitrais e, até mesmo, pela própria colaboração da irmã natureza, ao redor da igreja.

Muitas outras dioceses, como a de Santos e algumas da Bahia, também assumem em seus sites o termo "turismo religioso"; oferecem fotos, pacotes e textos explicativos sobre lugares, monumentos e igrejas.

\section{O turismo religioso entre negócios e dicionários}

Contudo, ao se confrontarem as expectativas divergentes de visitantes e fiéis, será preciso, então, caracterizar a diversidade do deslocamento, perguntando-se o que diferencia o deslocamento-viagem do deslocamento-turismo, e o deslocamentoperegrinação/romaria em relação ao deslocamento-excursão. Mas onde está o "adjetivo" popular na expressão turismo religioso? Na massa de visitantes que acorrem a esses locais? Nas classes marginalizadas e de baixo poder aquisitivo? Entretanto, o número de peregrinos, turistas e romeiros é bem alto (Salgado, 2003):

A los centros de culto religioso más grandes en el mundo cristiano, que atraen en total a casi 25 millones de peregrinos (el 15\% de los fieles migratorios de esta religión), pertenecen: Roma con el Vaticano (aproximadamente 8 millones), Lourdes (6 millones), Claromontana (4-5 millones), Fatima (4 millones) y Guadalupe, México (2 millones.). Entre los santuarios cristianos, un papel importante lo desempeñan los santuarios marianos. [...] La mayoría de los lugares de peregrinación del cristianismo está relacionada con el culto de la Virgen (alrededor del 80\%).

Assim, o santuário, a praça, a cruz e a imagem são desterritorializados pela força do fluxo semiótico no entrecruzamento dos significados produzidos pelos diversos grupos sociais (turistas, adeptos, eclesiásticos, especialistas em turismo etc.).Diante de uma catedral, o adepto ajoelha e reza. O turista fotografa, observa Será que se poderia afirmar que ambos desempenham um papel que poderia ser homogeneamente descrito de turismo religioso?

Para se ter uma idéia do abismo entre o adepto e o turista, pode-se ver a descrição de Brandão (2001) sobre a Semana Santa em Ouro Preto (MG):

Ainda que em maioria católica, os turistas que chegam a Ouro Preto em caravanas, as quais as empresas de turismo promovem, não vêm por um igual espírito religioso. No fundo, é preceito canônico que cada católico viva a Semana Santa em sua paróquia. Participar das cerimônias [...], em Ouro Preto, significa vivêlas como uma "rara experiência de cultura". Dificilmente estarão imbuídos dos sentimentos de pesar e dor que a igreja codifica e prescreve [...]. Se, para os devotos do lugar, a festa vale como culto, e o sinal dele é a dor; para o turista, o culto vale como festa, e o símbolo dela é a alegria da rara novidade. Deixarão de comer carne, fazer jejum [...] e evitar as delícias do sexo na "Sexta-Feira Santa"? [...] Não faltarão jovens, e, para eles, os bares e outros locais coletivos de alegria e "curtição" terão de permanecer abertos.

Entretanto, os turistas consomem, artesanatos e outros produtos, em restaurantes, fazem circular renda nas economias local, nacional e internacional Turistas dormem em hospedarias, hotéis e pousadas. Para se ter uma idéia do volume de dinheiro envolvido nessas atividades, basta somar o "produto" de três santuários católicos:Lourdes, Fátima e Guadalupe. Ao todo, por ano, visitam esses santuários 23 milhões de pessoas, o que gera 11,5 bilhões de reais. Há imensos impactos para o turismo também; por exemplo, Lourdes é o segundo maior centro hoteleiro da França.

\section{Deslocamento, turismo e oportunidade de negócios}

O critério deslocamento ainda não é suficiente para a construção de tipologias turísticas, algo que irá criticar e apontar a insuficiência das teorias funcionalistas e fenomenológicas em suas tentativas de construção de um saber turístico próprio. A metamorfose da religiosidade e do fato turístico anuncia um tempo de descolamento da identidade de suas raízes locais/territoriais. Baudrillard (1983) acentuou que, na "pós-modernidade", a imagem adquiriu independência e preponderância sobre a realidade, uma magia peculiar, constituindo a sacralidade no sentido de reverência/adoração, termos relacionados à religião.

Indissociavelmente ligado à imagem, estaria o mercado de bens materiais e simbólicos, gerenciados por agentes institucionalizados (redes hoteleiras, operadoras de turismo etc.), com a participação do próprio Estado e dos agentes religiosos.

Com isso, o turismo passa a ser visto como uma oportunidade de negócios: criam-se empregos para guias, incrementa-se o artesanato em geral e o ligado às peças religiosas, aumenta-se a utilização da estrutura de apoio ao turismo etc. Segundo Melo (2000), da imprensa pernambucana:

Em breve, o Brasil também deve começar a apostar neste filão [turismo religioso]. Pelo menos, isso é o que espera a [...] EMBRATUR, com o lançamento 
do primeiro Calendário Oficial do Turismo Religioso Nacional, previsto para o final deste mês [06/2000]. Ainda em fase de elaboração, o projeto tem como objetivo catalogar e organizar pelo menos 20 roteiros da fé, entre as festas populares de maior atração do País.

O turismo teria sua dinâmica atrelada à imagem, aos modos de olhar (Urry, 1990) que, interagindo com outros fatores econômicos e sociais, direciona fluxos de pessoas pela (re)criação dos desejos e das necessidades. Assim, aos olhos de determinados agentes do mercado e de parte da instituição, o turismo religioso passa a encarnar-se no católico, que deposita aos pés da imagem, objeto de veneração, suas promessas.

Parece que o termo "turismo religioso" precisa ainda de uma análise crítica mais consistente e articulada a outros termos mais adequados aos fenômenos religiosos, como "peregrinação". No entanto, sob esse termo, quer se dê outro nome, a prática de visitar lugares, ir a eventos, festa de cunho religioso-popular, católica ou não, a comunidade local pode participar da organização do "turismo" ou sofrer seus impactos sem voz ativa.

Assim, se no plano biológico existe um certo número de necessidades, a inevitável interação com a sociedade produz os desejos ou, como diriam Deleuze e Guattari (1996), "as máquinas desejantes", mediados pela multiplicação "agônica" de imagens, metamorfoseados em mil formas, fragmentando-se continuamente.

A condição de "mercantilização" dos lugares e da religião, com seu aparato de festas e tradições populares, ou seja, a de torná-los desejáveis porque comercializáveis, está na confecção de imagens. E é aí, no imaginário veiculado pelas mídias e em interação com o fluxo de visitantes/turistas, que turismo e religião vão encontrar seu ponto de convergência e o tecido no qual vão estar alinhavados pelo consumo. A religião torna-se espetáculo e performance, não só pelo olhar do turista, mas pelo próprio olhar do adepto, à medida que as modernas transformações culturais vão impactando a maneira como os fiéis manifestam e vivem suas religiões.

As agências de viagens, de olho no filão, organizam pacotes para lugares, eventos, festas sagradas como Lourdes, Fátima, Roma, Medjugorje (Bósnia-Herzegovinia, ex-Iugoslávia), os cenários bíblicos em Israel (Jerusalém, especialmente), que atraem cerca de 25 milhões de visitantes anualmente (Savola, 2003). Isso sem serem mencionados os principais pontos da América Latina: Nossa Senhora de Guadalupe, no México; Luján, na Argentina, entre outros. O Quadro 1, a seguir, lista algumas possibilidades de negócios envolvidos no turismo religioso.
Quadro 1. Possibilidades de negócio em relação ao aproveitamento turístico da religião

\section{Atividades Socioeconômicas Envolvidas no Turismo Religioso}

Agências de viagem de turismo religioso

Agências de viagem em geral

Transporte aéreo e rodoviário

Sistemas de hospedagem, incluindo casas de aluguel para temporada

Artesanato de artigos religiosos

Indústrias de itens religiosos

Comércio local em geral

Serviços de apoio (aluguel de carros, diversão)

Como se pode depreender até aqui, a gama de negócios aberta pela exploração desse rico filão cultural é ampla e mal começou a ser estudada e levada a sério pelos agentes de turismo; mas, para que haja resultados, é necessário planejá-los e aproveitá-los.

\section{À guisa de conclusão}

É necessário detectar-se a naturalização de determinadas relações culturais feitas na análise do termo turismo religioso. Essa fenomenologia analítica estabeleceria uma "zona de contato" complexa, pois envolve toda a estrutura do mercado turístico (agências, hospedagem, transportes, serviços etc.) em tantos locais e regiões do Brasil. Contato que não quer dizer necessariamente aceitação, harmonia, pois conflito, guerra, crise também constituem relações de contato.

O peregrino que, pela fé, visita um santuário, paga promessas e reza, vivencia ontologicamente a realidade à qual está ligado. Já o turista que "participa", observa e consomelembranças, consome a vivência metaforicamente. Segundo Steil (2003), a ontologia diz respeito ao ser (essência) das coisas, dos fenômenos e dos eventos, uma "internalidade", e a metáfora aponta para a representação performática da realidade, uma "externalidade".

Existem conflitos entre os sentimentos de turistas e moradores, ainda que os visitantes também se declarem católicos. Contudo, para ser "fiel" ao "espírito pós-moderno", não convém absolutizar esses esquemas interpretativos, pois há elementos "transversais".

O consumo/mercado seria um deles, pois tanto o peregrino quanto o turista consomem objetos, peças artesanais ou industrializadas, nacionais ou importados, produzindo significados para sua situação social e sua conduta, por sua vez ligadas 
a diferenciações culturais e econômicas. Tanto em um quanto no outro, crenças e ritos são mediados pelo mercado. Então, a globalização promoveu tanto o contato intercultural dos diversos sistemas religiosos quanto criou as condições da mercantilização do campo religioso (Steil, 2003) e, assim, permitiu o desmoronamento de fronteiras entre o turismo e a religião, fatores essenciais na constituição do novo termo "turismo religioso".

A porosidade entre as fronteiras leva também a uma crise nos conceitos tradicionais que não mais captam e traduzem os fenômenos que tentam compreender. Há um fluxo nômade das práticas sociais que mesclam religiosidade, prazer, consumo e comércio que ainda escapa à teorização acadêmica. Em relação às fronteiras da religião, quando se ouvem músicas do Padre Marcelo no Carnaval, pergunta-se se a religião tornou-se espetáculo e performance, oferecidos a consumidores errantes, a experimentadores de sensaçōes, que não se vinculam a dogmas, a sistemas teológicos nem a igrejas. Aí, talvez se possa falar em "turismo religioso".

Isso remete à forma como se vive a religiosidade atualmente. $\mathrm{Na}$ contemporaneidade, a filiação religiosa pode ser vivida como uma escolha ou como uma tradição. No entanto, há uma intensa visibilidade dessas escolhas, correlacionada a uma nova forma de mercantilização dos símbolos religiosos: o seu aproveitamento turístico. Entretanto, o termo turismo religioso é cada vez mais usado e possui uma base empírica: as manifestaçōes de fé e religiosidade tornam-se, na sociedade de consumo atual, espetáculos artísticos, culturais e turísticos (Felipe, 2001). Portanto, se a concepção de religioso e profano muda (Amaral, 2001), é possível a existência e o uso de termos como turismo religioso.

Todavia, este artigo limitou-se a analisar essa imbricação entre turismo e religião do ponto de vista do Catolicismo. Mas ainda falta um estudo maior da contribuição de outras religiōes, como a Umbanda, que tem dado origem a eventos e a festas concorridos e afinados com o turismo, por exemplo, os ritos de honra a Iemanjá, por ocasiāo da passagem de ano. O Candomblé é, particularmente na Bahia, outra manifestação religiosa que possui forte relação com a atividade turística, desde os acarajés até os ritos tradicionais, como a lavagem das escadarias da Igreja do Bonfim. Por outro lado, os megaeventos de gospel (estilo musical de origem evangélica) das igrejas protestantes e pentecostais atraem adeptos e turistas. Talvez, nesses deslocamentos contemporâneos, "pós-modernos", essas categorias sejam indissociáveis na prática. $\mathrm{Na}$ teoria, as fronteiras são bem mais nítidas do que na realidade.

Mas fica uma questão, conceitual decerto, mas não menos importante do que as oportunidades de negócio abertas: turismo religioso ou, simplesmente, aproveitamento turístico de festas, eventos e lugares religiosos? O termo "turismo religioso" torna-se uma arena, um local onde se realiza a circulação e a negociação entre vários contextos de interlocução: a Igreja Católica, os pastores evangélicos, os governos, as comunidades locais, os peregrinos e os turistas. Os sentidos circulam e são consumidos, sendo que o lugar da fala aciona um dispositivo de produção de significados. Esse contexto situacional (quem fala de onde fala?) se coaduna com o contexto existencial (quem é aquele que fala?), aciona o intertexto, no caso, a categoria "turismo religioso", que seria assim um intertexto produzido em um mercado simultaneamente simbólico/político/econômico, onde funciona a lógica do poder "fazer ver, fazer crer".

Nesse sentido, não se pode separar a categoria "turismo religioso" dos embates e conflitos sobre a legitimidade do uso, sobre a autenticidade e/ou cientificidade do termo em questão. Contudo, tal embate se dá em uma arena em que os interlocutores possuem condiçōes desiguais: diferentes níveis de capital social, cultural, econômico e simbólico.

Entretanto, é nessa circulação comunicativa que a categoria se afirma, emerge, é legitimada. Talvez aí se possa traçar um paralelo entre o processo de construção da categoria e a própria categoria: circulação de pessoas, de fluxos simbólicos e financeiros, reunindo-se na mesma fronteira o consumo (Veblen, 1953). Enfim, pode-se afirmar que o turismo religioso seja uma das expressōes (metafóricas e práticas) em que emerge a transição do fordismo ao modelo de acumulação flexível do capital, tal como Harvey (1989) propôs. Mas isso já é uma outra história, um outro intertexto. De novo a circulação dos sentidos se reinicia, o fluxo semântico continua, solene e indomável.

\section{Referências bibliográficas}

ALMEIDA, Renato. 1972. A recreação popular, suas formas e expressōes. In: DIÉGUES IR, Manuel (Coord.). História da cultura brasileira. Rio De Janeiro: MEC. v. 1, p. 201-213.

AMARAL, Leila. 2001. Deus épop: sobre a radicalidade do trânsito religioso na cultura popular de consumo. SIMPOSIO NACIONAL A ASSOCIAÇÃO BRASILEIRA DE HISTÓRIA AS RFLIIIIOEES, 3. Recife, 20-22 de jun. 2001

APPADURAI, Arjun. 1996. Modernity at large: cultural dimensions of globalization. Minneapolis/Lenders: University of Minnesota Press.

ARQUIDIOCESE de Belo Horizonte. 2003. Turismo religioso. Disponivel em: $<$ http://www.arquidiocesebh.org.br/diversos/turismo/default.Asp. > Acesso em: 12 set. 2003.

ARRUDA, Roldão \& HENRIQUE, Brás. 1999. Crença popular estimula turismo religioso em São Paulo. O Estado de S. Paulo, Caderno Cidades, 16 jun.

ASSUNÇÃO, Luís Fernando. 2002. Canonização evidencia turismo religioso em Santa Catarina: padres, feiras e até uma agência são especializados em roteiros santos. A Notícia, Geral, Santa Catarina, 10 mar.

BARRETTO, Margarita. 2001. As ciências sociais aplicadas ao turismo. In: SERRANO, Célia, BRUHNS, Heloísa Turini \& LUCHIARI, Maria Tereza D. P. (Orgs.). Olhares contemporâneos sobre o turismo. 2. ed. Campinas, sP: Papirus.

BASSETI, Luiz Cláudio 2003. Secretório de turismo e meio ambiente reúne-se com evangélicos. Disponivel em: <http://www.pontagrossa.pr.gov.br/ccs/20010705/secretário./html>. Acesso em: 15 set. 2003. 
BAUMAN, Zygmunt. 1998. O mal-estar da pós-modernidade. Rio de Janeiro: Jorge Zahar. BELTRĀO, Luiz. 1980. Folkcomunicação: a comunicaçāo dos marginalizados. Sāo Paulo: Cortez. BOYER, Marc. 2003. História do turismo de massa. Bauru: EDusC.

BUYSE, Bruno Dorfman \& Evangelista, Rafael. 2001. A Festa do Divino em Sāo Luís do Paraitinga: a cultura popular está acabando? Disponível em: <http://www.uol.com.br/cienciahoje/chmais/pass/ch189/divino. pdf $>$. Acesso em: 12 mar. 2003.

BRANDÃO, Carlos Rodrigues. 2001. Ouro Preto: arte, antiguidade e artesanato. In: A cultura na rua. 2. ed. Campinas, SP: Papirus.

CAMINHO Santo a Nhá Chica. 2002. CorreioBraziliense. Disponivel em:<.http://www2.correioweb.com. br/cw/edicao_20020417/sup_lug_170402_5.htm.>. Acesso em: 13 set. 2002.

CANCLINI, Néstor Garcia. 2000. Culturas hibridas: estratégias para entrar e sair da modernidade. Sāo Paulo: EDUSP.

CARVALHO, Adriany R. de Matos. 2002. O turismo religioso e o lazer popular: as peregrinaçōes em sāo Se verino dos Ramos como turismo religioso. Dissertaçāo (Mestrado em Comunicaçāo Social) - Universidade Federal Rural de Pernambuco.

CARVALHO, José Jorge de. 1999. Um espaço público encantado: pluralidade religiosa e modernidade no Brasil. Texto Avulso. UnB.

CASCUDO, Luiz da Câmara. 1954. Dicionário do folclore brasileiro. Rio de Janeiro: Instituto Nacional do Livro.

CRISTOFOLI, Ãngelo R. 2003. Humanismo latino e turismo religioso no Brasil. Disponível em: $<$ http://www. brasillatino.pro.br/colunas/angelo_r_cristofoli. htm>. Acesso em: 7 set. 2003.

DA MATTA, Roberto. 1994. O que faz o brasil, Brasil? 7. ed. Rio de Janeiro: Rocco.

DELEUZE, Gilles \& GUATTARI, Félix. 1996. O anti-Édipo: capitalismo e esquizofrenia. Lisboa: Assírio \& Alvim.

DIAS, Reinaldo. 2003. Sociologia do turismo. Sāo Paulo: Atlas.

DIAS, Reinaldo \& SILVEIRA, Emerson Sena da. 2003. Turismo religioso: ensaios e reflexões. Campinas, SP: Alínea.

DIOCESE de Santos. 2003. Turismo religioso no litoral. Presença Diocesana, ano 1, n. 11, jul. 2002.

Festa do Santo Daime. 2003. Disponível em: <.http://www.citybrazil.com.br/ac/riobranco/agenda.htm> Acesso em: 10 jun. 2003.

FELIPE, Carlos. 2001. A fé que atrai e emociona os visitantes. Estado de Minas, Turismo, 5 abr., p. 12.

FOUCAULT, Michel. 2001. A ordem do discurso. Sāo Paulo: Loyola.

FUNDAÇÃO Instituto de Pesquisas Econômicas - FIPE. 2002. Caracterização e dimensionamento do turismo doméstico no Brasil. São Paulo: FIPE.

GAZONI, Jefferson. 2003. Aproveitamento turístico de recursos mítico-religiosos: os passos de Anchieta. In: DIAS, Reinaldo \& Silveira, Emerson J. Sena da. Turismo religioso: ensaios e reflexões. Campinas, SP: Alínea, 2003.

GEERTZ, Clifford. 1997. O saber local. Petrópolis: Vozes.

GONÇALVES, Claudenir. 2003. Potirendaba investe no turismo religioso. In: Potirendaba em ação: site oficial da Prefeitura de Potirendaba, sp. Disponível em: <http://www.pmpotirendaba.com.br/notícias2. asp?cód $=29>$. Acesso em: 15 set. 2003.

HERVIEU-LÉGER, Danièle. 1997. Representam os surtos emocionais contemporâneos o fim da secularizaçāo ou o fim da religião? In: Religião e sociedade. Rio de Janeiro: CER/ISER, v. 18, n. 1.

IMPACTOS do turismo. 2003. Disponível em: <http://revista.fapemig.br/5/circuito $>$. Acesso em: 13 set. MAFFESOLI, Michel. 2001. Sobre o nomadismo: vagabundagens pós-modernas. Rio de Janeiro: Record.
MAUSS, Marcel. 1972. Manual de etnografia. Porto: Editorial Pórtico.

MELO, Juliana de. 2000. Um mapa do turismo religioso no Brasil. Jornal do Comércio, Pernambuco, 8 jun., p. 13.

MONTEIRO, Manoella. 2003. Turismo religioso: roteiros de fé. Disponivel em: $<$ http://www.noolhar.com/ opovo/turismo/301668.html . Acesso em: 10 jun. 2003.

OMENA, Tânia Guimarāes. 1989. A procura do equilíbrio do mercado turístico. Boletim Técnico Senac, v. 15, n. 1, p. 29-39, jan/abr.

PEREIRA, Amanda Casarin. 2003. O perfil do visitante na festa do jubileu de senador Firmino, SP. Santos Dumont: Faculdade de Turismo de Santos Dumont (monografia).

PEREZ, Lea de Freitas. 2000. Breves notas e reflexões sobre a religiosidade brasileira. Brasil 500 Anos. Belo Horizonte: Imprensa Oficial dos Poderes do Estado. p. 40-58.

PONTIFICIO Consejo para la Pastoral de los Emigrantes e itinerantes. 2003. Orientaciones para la pastoral del turismo. Disponivel em: $<$ http://www.vatican.va/roman_curia/pontifical_councils/migrants/documents/ rc_pc_migrants_doc_20010711_pastorale-turismo_sp.html >. Acesso em: 10 set. 2003.

RABAHY, Wilson Abrahāo. 2002. Caracterizaçāo do turismo: uma análise das motivações "feiras e congressos" e "religiosa". Caderno de Estatisticas. São Paulo: SIDETUR, v. 13.

SALGADO, Javier Robles. 2003. Turismo religioso: alternativa de apoyo a la preservación del patrimonio y desarrollo. Disponível em: $<$ http://www.aguaforte.com/antropologia/javiersalgado.Html $>$. Acesso em: 13 set. 2003.

SAVOLA, Claudio. 2003. El turismo religioso ya mueve millones por el país y el mundo. Clarín, Cuadernos Sociedad, Buenos Aires, 22 sep., p. 3.

SECALL, Rafael Esteve. 2003. Turismo y religión: aproximación a la historia del turismo religioso. Universidad de Málaga. Servicio de Publicaciones e Intercâmbio Científico, 2002.

SENAC Florianópolis. 2003. Grade de horário do turismo religioso, Disponivel em: $<$ http://www.fpolis. sc.senac.br/turismo/turreligioso.htm>. Acesso em: 13 set. 2003.

SILVA, Cristina Schmidt. 2000. Viva São Benedito! Festa popular e turismo religioso em tempos de globalizaçāo. Aparecida: Santuário.

SILVEIRA, Emerson Sena da. 2003. Turismo e consumo: a religiāo como lazer em Aparecida. In ABUMANSSUR, Edin Sued. (Org.). Turismo religioso: ensaios antropológicos sobre religiāo e turismo. Campinas, sP: Papirus. p. 69-106.

SCHAUFFERT, Olinda T. 2001. Festa do Divino Espírito Santo: ritual religioso e atraçāo turística em Penha -SC. IV RAM, Curitiba, nov.

STEIL, Carlos Alberto. 1998. Peregriną̧ão e turismo: o Natal Luz em Gramado e Canela. REUNIĀO DA ANPOCS, 22. Caxambu.

2003. Peregrinação, romaria eturismo religioso: raízes etimológicas e interpretações antropológicas. In: ABUMANSSUR, Edin Sued. (Org.). Turismo religioso: ensaios antropológicos sobre religiāo e turismo. Campinas, sP: Papirus. p. 29-52.

TEIXEIRA, Sérgio Alves. 1988 Os recados das festas, Rio de Janeiro: FUNARTE.

TURISMO religioso rende bilhões. 2003. Diárionet, Recife, 11 abr. 1998. Disponivel em: $<$ http://www.dpnet. com.br/anteriores/1998/04/11/econo_0.html>. Acessado em: 15 set. 2003.

Recebido em: 01/07/2005

Aprovado em: 30/03/2006. 